Universidad de Lima

Facultad de Derecho

Carrera de Derecho

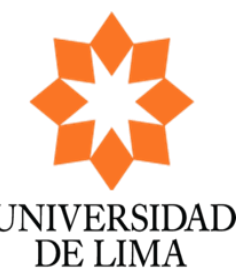

DE LIMA

\title{
CIVIL: "NULIDAD DE ACTO JURÍDICO" Y ADMINISTRATIVO: "PROTECCIÓN AL CONSUMIDOR"
}

Trabajo de Suficiencia Profesional para optar el Título Profesional de Abogado

\section{FERNANDO ARTURO CAMARGO VALVERDE}

Código: 20081265

\section{Lima -Perú}

Noviembre, 2019 


\title{
CIVIL: "NULIDAD DE ACTO JURÍDICO"
}

Materia: Nulidad de Acto Jurídico

Demandante: S. L. V.

Demandados: Municipalidad Metropolitana de Lima y Notaría Pública de Lima M. C.

Expediente No: $\quad$ 12059-2011

Resumen:

El expediente trata acerca de un proceso de nulidad de acto jurídico, en el cual se discute si es factible jurídicamente que una autoridad administrativa adquiera dominio vía usucapión de un inmueble cuya posesión obtuvo en el marco de un procedimiento expropiatorio inconcluso.

\section{ADMINISTRATIVO: "PROTECCIÓN AL CONSUMIDOR"}

\author{
Materia: Protección al Consumidor \\ Demandante: Sede Norte \\ Demandado: P. A. L. S. A. \\ Expediente $\mathrm{N}^{\circ}$ : $\quad$ 160-2013/ILN-CPC
}

Resumen:

El presente informe legal tiene por contenido el análisis legal, jurisprudencial y doctrinario de un procedimiento administrativo sancionador, en el cual se discutió si en el marco de un servicio de transporte aéreo de pasajeros es una garantía legal el que las empresas de transporte cuenten con un procedimiento para la declaración de valor de equipaje. 
